\title{
Editorial
}

\section{Litiasis renal en Paraguay: herramientas laboratoriales en la identificación de etiología y seguimiento del paciente litiásico}

La litiasis renal es una patología que se caracteriza por la formación, agregación y retención de cristales en las vías urinarias. Su etiología es compleja ya que la misma puede ser el resultado de la interacción de múltiples factores tanto endógeno, metabólico como ambiental. La elevada tasa de recurrencia de la formación de cálculos puede superar el $40 \%$ en un periodo de 5 años tras el primer episodio y puede conllevar consecuencias graves para el funcionamiento renal con su consiguiente impacto en la calidad de vida del paciente ${ }^{(1,2)}$.

La evaluación del paciente litiásico requiere de varias etapas, incluyendo la evaluación clínica, estudios de imágenes, estudios laboratoriales específicos, que en conjunto permitan identificar el origen de la patología. La identificación precisa de las causas que originaron la formación del cálculo urinario es esencial para la elección de medidas terapéuticas apropiadas y específicas para cada paciente ${ }^{(1)}$.

El laboratorio clínico brinda información relevante en la investigación etiológica permitiendo el análisis de la composición del cálculo, el análisis de las concentraciones de compuestos promotores e inhibidores de la cristalización y conocido como perfil metabólico, además del análisis integrado de estas concentraciones mediante el uso de software específicos que permiten identificar índices de saturación urinaria en un momento específico. En el seguimiento del paciente mediante estudios seriados de cristaluria, realizados según protocolos internacionales con una frecuencia de al menos 3 al año, permite evaluar la eficacia de las medidas terapéuticas de forma temprana ${ }^{(3-5)}$.

El análisis del cálculo empleando métodos físicos combinados y empleando la clasificación morfológica descrita por Daudon y colaboradores, ha sido implementada en el país desde el año $2007^{(6)}$. Este tipo de metodología presenta múltiples ventajas respecto al análisis químico convencional, que incluye la sensibilidad suficiente para detección de elementos traza, el estudio del cálculo por estratos identificando la cronología de formación del mismo, la capacidad de identificación de formas cristalinas incluso en mezclas complejas, así como la identificación de compuestos como Xantina, fármacos y otros. Estas características permiten el reconocimiento de factores etiológicos durante la formación de los cálculos. Varios estudios realizados señalan que en concordancia con países occidentales la litiasis oxalocálcica es la más frecuente en el Paraguay, mientras que por otra parte aquellos cálculos voluminosos y que requieren intervenciones urológicas invasivas para su remoción se suman los factores infecciosos que desencadenan las litiasis por carbapatita y estruvita ${ }^{(7-10)}$.

La evaluación metabólica es útil para la detección de concentraciones elevadas de promotores de cristalización o bien el déficit de inhibidores de cristalización presentes en el momento del análisis $^{(11)}$. Los analitos incluidos pueden variar ampliamente según protocolos empleados. Diversos artículos con datos nacionales muestran de forma llamativa a la hipocitraturia como uno de los factores más frecuentes tanto en adultos como en niños, seguida de la hipercalciuria, así como también un volumen de diuresis insuficiente que conlleva a fenómenos de concentración es también un hecho destacable ${ }^{(12-14)}$. La interpretación de estos valores de forma individual resulta un proceso complejo. La incorporación de herramientas informáticas para el análisis integrado de los datos del perfil metabólico y la generación de verdaderos índices de riesgo de cristalización es un avance importante. Estas herramientas han sido empleadas en el país tanto para una evaluación de base pre tratamiento, así como en la fase post tratamiento, mostrando diferencias significativas en el volumen de diuresis de los pacientes post tratamiento, así como una disminución significativa del riesgo de cristalización de ácido úrico tras 6 meses de seguimiento ${ }^{(15)}$.

El empleo de la cristaluria como marcador del riesgo de cristalización y herramienta de seguimiento del paciente litiásico es recomendada internacionalmente debido a la simplicidad de la técnica y la utilidad de la misma para prever riesgos de recidiva ${ }^{(5)}$. Este marcador se ha empleado de forma usual en el seguimiento de pacientes litiásicos pediátricos, con una disminución marcada en la presencia de cristales en la fase de tratamiento, mostrando la eficacia de las medidas terapéuticas. Por otra parte ha demostrado ser crucial en el seguimiento de un caso de litiasis genética por cistinuria empleando el parámetro de volumen cristalino global y ha permitido la identificación precisa de cristales cuya morfología inusual y que se encontraban asociados a fármacos, más específicamente a antibióticos ${ }^{(16-18)}$. 
La incorporación de las técnicas especializadas en el área de la bioquímica de la litiasis renal hacen posible que aquellos pacientes afectados por esta patología puedan tener acceso a las herramientas necesarias para la elección de medidas terapéuticas específicas y por tanto reduzcan el riesgo de recidivas de forma tangible, con la mejoría en las condiciones de calidad de vida. Sin embargo, a pesar del esfuerzo realizado hasta el momento, es importante resaltar que este tipo de emprendimiento requiere de mayores inversiones a nivel público que permitan el acceso a un número mayor de pacientes a esta posibilidad diagnóstica.

Dra. Rosa María Guillén Fretes (Ph D) Docente Investigador, IICS, UNA Nivel II PRONII

\section{REFERENCIAS BIBLIOGRÁFICAS}

1. Nagaraja P, Premminger G, Kavangh J. Urinary tract stone disease. Londres: Springer; 2011.720 p.

2. Daudon M, Traxer O, Lechevallier E, Saussine C. [Lithogenesis]. Progres En Urol J Assoc Francaise Urol Soc Francaise Urol. 2008 Dec;18(12):815-27.

3. Daudon M, Bouzidi H, Bazin D. Composition and morphology of phosphate stones and their relation with etiology. Urol Res. 2010 Dec;38(6):459-67.

4. Bazin D, Letavernier E, Haymann J-P, Méria P, Daudon M. [The role of physicochemistry in urology and nephrology, selected results obtained during the last ten years]. Progres En Urol J Assoc Francaise Urol Soc Francaise Urol. 2016 Oct;26(11-12):608-18.

5. Daudon M, Frochot V. Crystalluria. Clin Chem Lab Med. 2015 Nov;53 Suppl 2:s1479-1487.

6. Daudon $M$, Bader $C A$, Jungers $P$. Urinary calculi: review of classification methods and correlations with etiology. Scanning Microsc. 1993 Sep;7(3):1081-104; discussion 1104-1106.

7. Guillén, R, Pistilli, N, Ramírez, A, Echague, G. Estudio morfológico de cálculos urinarios de pacientes que concurren al IICS en el 2007. Mem Inst Investig Cienc Salud. 2008;4(2):11-7.

8. Guillén, R, Funes, $P$, Echague, G. Análisis morfológico de cálculos urinarios voluminosos y coraliformes. Mem Inst Investig Cienc Salud. 2016;14(2):61-7.

9. Daudon M. [Epidemiology of nephrolithiasis in France]. Ann Urol. 2005 Dec;39(6):209-31.

10. Mehrsai A, Taghizadeh Afshar A, Zohrevand R, Djaladat H, Steffes $H$, Hesse A, et al. Evaluation of urinary calculi by infrared spectroscopy. Urol J. 2004;1(3):191-4.

11. Areses Trapote R, Urbieta Garagorri MA, Ubetagoyena Arrieta M, Mingo Monge T, Arruebarrena Lizarraga D. [Evaluation of renal stone disease: metabolic study]. An Pediatría Barc Spain 2003. 2004 Nov;61(5):418-27.

12. Guillén, R, Ruíz, I, Stanley, J, Ramírez, A, Pistilli, N. Evaluación de parámetros litogénicos con urolitiasis que concurrieron al Instituto de Investigaciones en Ciencias de la Salud en el año 2009. Mem Inst Investig Cienc Salud. 2010;8(1):14-21.

13. Guillén, R, Ruíz, I, Stanley, J, Ramírez, A, Pistilli, N, Valiente, N, et al. Evaluación metabólica de pacientes pediátricos con urolitiasis. Pediatr Asunción. 2011;38(2):87-92.

14. Funes $P$, Echagüe G, Ruiz I, Rivas L, Zenteno J, Guillén R. [Lithogenic risk in patients from Paraguay with urolithiasis]. Rev Med Chil. 2016 Jun;144(6):716-22.

15. Guillén R, Ramos C, Ayala R, Funes P, Ruiz I, Zenteno J, et al. [Lithogenic risk index in urinary lithiasis patients and their evolution after treatment.]. Arch Esp Urol. 2017 Oct;70(8):725-31.

16. Funes, P R I, Rivas L, Zenteno J, Granado D, Echague, G, Guillén, R. Cristaluria en niños litiásicos que concurrieron al IICS-2011-2013. Pediatr Asunción. 2016;43(2):123-8.

17. Guillén, R, Funes, P, Ruiz, I, Duarte, C, Mereles, B. Litiasis por cistina: Reporte de un caso. Mem Inst Investig Cienc Salud. 2014;12(1):51-6.

18. Guillén, R, Franco, L, Sánchez, G, Ortíz V, Herebia L, Ruiz, I, et al. Cristalurias medicamentosas en el laboratorio de urgencias: Reporte de dos casos. Mem Inst Investig Cienc Salud. 2016;14(2):1069.

\section{Nephrolithiasis in Paraguay: Laboratory tools in the identification of etiology and follow-up of the lithiasic patient}

Nephrolithiasis is a disease characterized by the formation, aggregation and retention of crystals in the urinary tract. Its etiology is complex since it can be the result of the interaction of multiple endogenous, metabolic and environmental factors. The high rate of recurrence of stone formation can exceed $40 \%$ in a period of 5 years after the first episode and it can lead to serious consequences for kidney function with its impact on the life quality of the patient ${ }^{(1,2)}$.

The evaluation of the lithiasic patient requires several stages, including clinical evaluation, imaging studies, specific laboratory studies, which together allow the identification of the origin of the pathology. The precise identification of the causes that 
originated the formation of the urinary stone is essential for the selection of appropriate and specific therapeutic measures for each patient ${ }^{(1)}$.

The clinical laboratory provides relevant information in etiological research allowing the analysis of the composition of the stone and the concentrations of crystallization promoter and inhibitors compounds known as metabolic profile, in addition to the integrated analysis of these concentrations through the use of specific software that allow the identification of urinary saturation rates at a specific time. In the follow-upof the patient through serial studies of crystalluria, carried out according to international protocols with a frequency of at least three per year, allows the early evaluation the efficacy of therapeutic measures ${ }^{(3-5)}$.

The analysis of the kidney stone using combined physical methods and the morphological classification described by Daudon et al. has been implemented in the country since $2007^{(6)}$. This type of methodology has multiple advantages with respect to conventional chemical analysis, which includes sufficient sensitivity for trace element detection, the study of the stone per stratum identifying the chronology of formation, the ability to detect crystalline forms even in complex mixtures, and identifying compounds such as xanthine, and other drugs. These characteristics allow the recognition of etiological factors during the formation of the stones. Several studies indicate that in accordance with Western countries the oxalocalcic lithiasis is the most frequent in Paraguay. On the other hand, infectious factors, that trigger carbapatite and struvite stones, are added to those voluminous stones that require invasive urological interventions for their removal ${ }^{(7-10)}$.

The metabolic evaluation is useful for the detection of high concentrations of crystallization promoters or the deficit of crystallization inhibitors present at the time of analysis ${ }^{(11)}$. The analytes included can vary widely according to the protocols used. Several articles with national data show strikingly hypocitraturia as one of the most frequent factors in both adults and children, followed by hypercalciuria, as well as an insufficient diuresis volume that leads to a phenomenon of concentration which is also a remarkable fact ${ }^{(12-14)}$. The interpretation of these values individually is a complex process. The incorporation of computer tools for the integrated analysis of metabolic profile data and the generation of true crystallization risk indexes is an important advance. These tools have been used in the country both for a pre-treatment base evaluation, as well as in the post-treatment phase, showing significant differences in the diuresis volume of the post-treatment patients, as well as a significant decrease in the risk of uric acid crystallization after 6 months of follow-up ${ }^{(15)}$.

The use of crystalluria as a marker of the crystallization risk and follow-up tool of the lithiasic patient is recommended internationally due to the simplicity of the technique and its usefulness to predict relapse risks ${ }^{(5)}$. This marker has been used usually in the follow-up of pediatric lithiasic patients, with a marked decrease in the presence of crystals in the treatment phase, showing the efficacy of the therapeutic measures. On the other hand, it has proved been crucial in the follow-up of a case of genetic lithiasis by cystinuria using the global crystalline volume parameter and has allowed the precise identification of crystals with unusual morphology and that were associated with drugs, more specifically antibiotics ${ }^{(16-18)}$.

The incorporation of specialized biochemichal techniques in the area of renal lithiasis makes possible, for those patients affected by this pathology, to have access to the necessary tools for the choice of specific therapeutic measures and therefore reduce the risk of recurrence in a tangible way with the improvement in the quality of life conditions. However, despite the effort made so far, it is important to emphasize that this kind of enterprise requires greater public investments that allow access to a greater number of patients to this diagnostic possibility.

\section{Dr. Rosa María Guillén Fretes (Ph D)}

Teaching Researcher, IICS, UNA Categorized Level II PRONII, CONACYT 